\title{
The Incidence of Post-Anaesthetic Myopathy with the Use of a Static Air Mattress
}

\author{
Astrid B.M. Rijkenhuizen and P. van Dijk \\ Department of General and Large Animal Surgery, Utrecht University
}

\begin{abstract}
Summary
The effect of a static air mattress on the incidence of post-anaesthetic myopathy was studied. It is generally assumed that pressure on the muscles will result in an impairment of the circulation, creating an ischaemic condition and cause post-anaesthetic myopathy. An adequate muscular perfusion is maintained by careful positioning of the patient and paying attention to the surface on which the horse lies. As human literature, based on the evaluation of CT-scans of subjects supported by various types of beddings indicate, that the use of a static air mattress results in a significant reduction of compression and may result in lower incidence of ulcers, this type of mattres was selected to be tested for use in horses. In 19951349 horses were anaesthesized with an average anaesthesia time of 98 min. Twelve (0.9\%) horses had problems with the recovery because of myopathy. Nine limbs $(0.7 \%)$ concerned the underside of the horse during anaesthesia.
\end{abstract}

keywords post-anaesthetic myopathy, post-anaesthetic myositis, horse, post-anaesthetic lameness

\begin{abstract}
Häufigkeit der postnarkotischen Myopathie nach Verwendung einer statischen Luftmatratze
Die postnarkotische Myopathie (Muskeldysfunktion in Verbindung mit harter Schwellung und Schmerzhaftigkeit) entsteht durch Druckschämie des Muskelgewebes aufgrund der Lagerung während der Narkose. Bei der Reperfusion werden freie Radikale frei, die zur Myopathie führen, welche mit einer Inzidenz von 0,75 bis 6,4\% auftritt. Dieses Krankheitsbild ist wahrscheinlich die häufigste Ursache postoperativer Morbidität und Mortalität nach Anästhesie gesunder Pferde. Es liegt daher nahe, eine weiche Unterlage zu verwenden, um die Kompression zu vermindern. Es wurde die Häufigkeit der postnarkotischen Myopathie nach Einsatz einer Polyvinyl-Luftmatratze während der Vollnarkose von 1349 gesunden Pferden mit Halothan bestimmt. Der innere Luftdruck betrug ca. $25-30 \mathrm{mmHg}$, der eine Erhaltung der kapillären Perfusion gewährleisten soll. Eine Kontrolle des Druckes erfolgte durch manuelle Einschätzung der Zwischenräume. Die Matratze erwies sich als praktikabel und haltbar (im Schnitt 25 Pferde), wobei Löcher effektiv (weitere 20 Pferde) mit Methylacrylat oder Vinylflecken geflickt werden konnten. Die durchschnittliche Narkosedauer betrug 98 Minuten. 0,9\% der Pferde entwickelten eine postnarkotische Myopathie, wobei bei $0,7 \%$ nur die unten liegenden Körperregionen betroffen waren. Die Pferde hatten präoperativ keinerlei Störungen des Bewegungsapparates gezeigt, und die Narkose verlief ohne Zwischenfälle. Klinisch war eine gering- bis höchstgradige Lahmheit bzw. fehlende Stehfähigkeit zu beobachten, und die Pferde erholten sich nach Stunden bis zu 4 Tagen. Bei Betroffensein des M. triceps brachii ist ein tiefer Ellbogen auffällig, Überköten deutet auf Affektion des M. quadriceps hin und bei Erkrankung des M. Iongissimus dorsi zeigen die Pferde eine bilaterale harte Schwellung. Die Pferde sind bewegungsunwillig. Zur Verifizierung der Ergebnisse wäre eine direkte Messung des Gewebsdruckes in den Muskeln denkbar.
\end{abstract}

keywords: $\quad$ Muskelschäden, postnarkotische Lahmheit, postnarkotische Myopathie, Pferd

\section{Introduction}

Post-anaesthetic myopathy is probably the most common cause of morbidity and mortality in healthy horses presented for anaesthesia (Dodman et al. 1985, Klein 1990). The reported incidence of post-anaesthetic myopathy ranges from $0.75 \%$ to $6.4 \%$ of equine anaesthetic cases (Mc Carville and Blais 1986, Klein 1978, Richey et al. 1990, Peek 1993); on cattle no data are available.

It is generally assumed that pressure on the muscles will result in an impairment of the circulation, creating an ischaemic condition and cause myopathy (Lindsay et al. 1980, Weaver et al. 1984, Grandy et al. 1987, Lindsay et al. 1989, Serteyn et al. 1990, Hennig and Court 1991, Young 1993, Flaherty et al. 1996). Reperfusion of the ischaemic muscles post-operatively or by postural changes during anaesthesia, resulting in release of free radicals, could explain the muscular damage observed in equine post- anaesthetic myopathy (Serteyn et al. 1988, Serteyn et al. 1990).

Lindsay et al. (1985) and White and Suarez (1986) have proven that horses in lateral recumbency on a padded surface had a significant less interstitial pressure in the underlying triceps muscle than when the horses were positioned on a hard surface. Thus, an adequate padding and careful positioning of the patient during anaesthesia appear to be of utmost importance (Flaherty et al. 1996). Air mattresses, thick foam (Flaherty, Nolan and Reid 1996) or waterbeds (Lindsay et al. 1985) have been advised to be used for all but very short procedures.

This paper reports on the incidence of post-anaesthetic myopathy at the Department of General and Large Animal Surgery, Utrecht University, since the start of the use of the polyvinyl air mattress (Waffleß). 


\section{Materials and Methods}

The one room air mattress studied is constructed with a large number of holes (Fig. 1), creating cells which have broad intercommunications allowing for free transmission of pressure. It is available in various sizes. The mattresses used in this study had a total length of $218 \mathrm{~cm}$ and a width of $88 \mathrm{~cm}$.

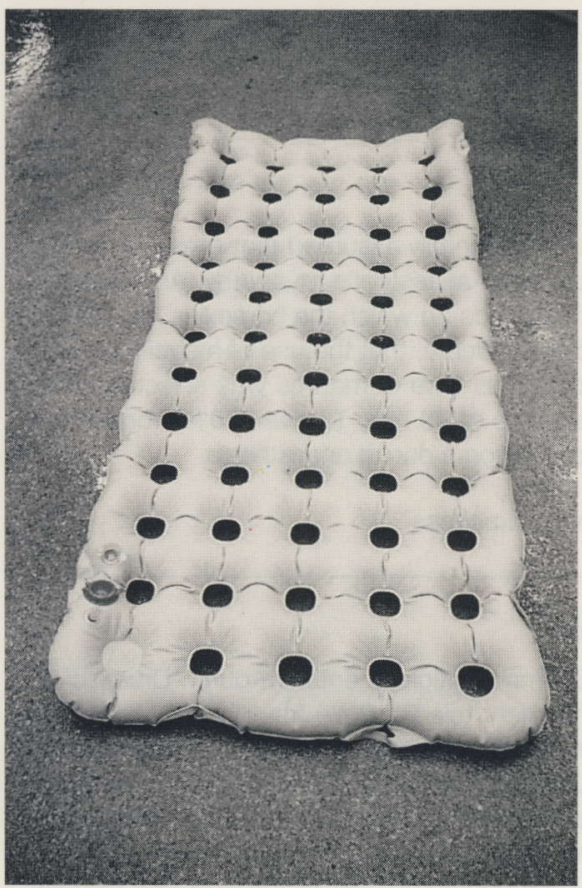

Fig. 1: The Waffle mattress

Die Waffle-Matratze

Although in human patients one mattress is sufficient to elevate the patient, it became clear that the insufflation pressure of 35 strokes of the Waffle MAD\& (Measured Air Delivery $E H O B B$ ) is insufficient for horses of about $600 \mathrm{~kg} \mathrm{BW}$. After various trials, the use of 2 three-folded mattresses lying next to each other seemed to function well. The mattresses were each inflated with approximately 20 strokes.

Under halothane anaesthesia the patients were elevated from the hard surface of the operation table and positioned on the inflated mattresses (Fig. 2 and 3). A hand was placed between the mattress and the surgery table to check the position of the patient. The pressure inside the mattress (25-30 mm Hg measured by use of a manometer) should be just enough to allow a hand to easily slide under the buttocks of the animal. If the pressure was to low, the mattress could be easily inflated with the MAD®. Only a minimal inflation was needed to lift the patient. If the pressure is too high, the air can easily be released through the inflation port which is located at one end of the mattress. Deflation is done rapidly in 2 to 3 seconds by pulling the tab at the port. With the three-folded mattress it is essential to position the patient such, as allow access to the valve at any time.

Patients were anesthetised following standard procedures used in our clinic. Premedication consisted of $5 \mathrm{mcg} / \mathrm{kg}$ de- tomidine I.V. (Domosedan®; Smith Kline, Holland) or acepromazine $(0.1 \mathrm{mg} / \mathrm{kg}) / \mathrm{methadon}(0.1 \mathrm{mg} / \mathrm{kg}) \mathrm{I}$.V. (Stehnarcoseß; A.U.V., Holland). Once sedation had taken effect guaifenesine $100 \mathrm{mg} / \mathrm{kg}$ as a $10 \%$ solution (Gujatal $\circledast$; Aesculaap B.V., Holland) with thiopentone $5 \mathrm{mg} / \mathrm{kg}$ (Nesdonal®, Rhône-Mérieux, Holland) was administered intravenously to achieve induction and lateral recumbency. The horses were intubated and halothane (Albic, Holland) was administered in a mixture of oxygen and nitrousoxide (60\%/40\%; $5 \mathrm{~L} / \mathrm{min})$ or $100 \%$ oxygen $(5 \mathrm{~L} / \mathrm{min})$ to maintain anaesthesia. Anaesthesia was monitored continuously by clinical examination and electronical devices (Hewlett Pack-

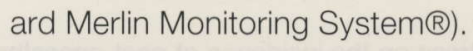

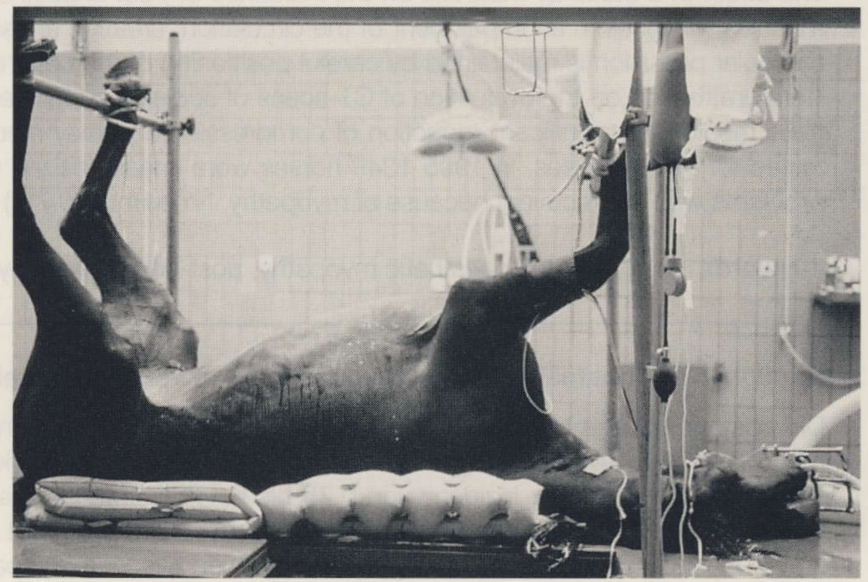

Fig. 2: A horse in dorsal recumbency positioned on the triple folded air mattress.

Ein Pferd in dorsaler Lagerung gebettet auf eine dreifach zusammengelegte Luftmatratze.

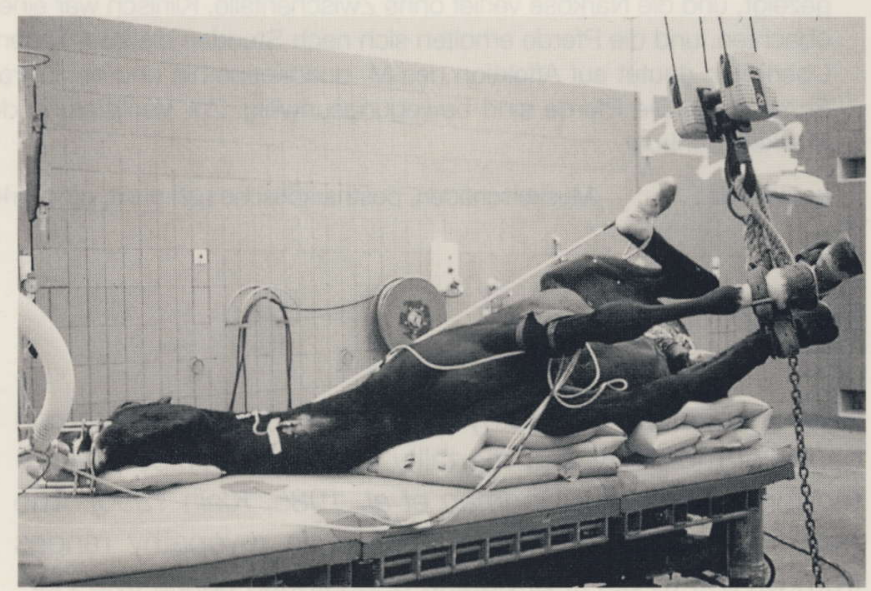

Fig. 3: A horse in lateral recumbency positioned on the triple folded air mattress.

Ein Pferd in lateraler Lagerung gebettet auf eine dreifach zusammengelegte Luftmatratze.

Body weight, breed, history, surgical procedure, position of the patient during anesthesia, stability of the patient on the mattress, pressure inside the mattress after positioning, duration and course of the anaesthesia and the lifetime of the mattresses were recorded. The patients were examined after they stood in the recovery box and efforts to ambulate became coordinated. A post-anaesthetic lameness was 
defined as myopathy when the horses showed clinical signs of muscle dysfunction combined with muscular swelling. In these cases, the muscles were hard on palpation, the patients were reluctant to walk, and appeared painful. The muscle groups included and the duration of the lameness were recorded. Transient knuckling at the fetlocks while attempting to stand was not recorded as lameness.

\section{Results}

\section{Mattress}

The patients stayed easily in position, because of the sufficient roughness of the mattress and the fact that the mattress was larger than the patient. Two three-folded mattresses and a head mattress were of sufficient size to properly support the horse's whole body and small enough not to be cumbersome for the surgeon. The mattresses were easy to handle and desinfect.

One mattress could be used for an average of 25 horses before leakage occurred. Leakage was generally seen at the seal of the holes, but could also be the consequence of an inadvertent perforation by the surgeon with a scalpel blade or towel clamp forceps. The places of leakage were sealed with methylacrylate. For larger holes a vinyl patch was used. After repair the mattresses could be used for another 20 horses.

\section{Patients}

In 19951349 horses were anaesthesized with an average anaesthesia time of $98 \mathrm{~min}$. Twelve $(0.9 \%)$ horses had problems during the recovery because of myopathy (Table 1). Three of the 9 front limbs concerned the upper limb. All 12 horses (bodyweight between 400 and $840 \mathrm{~kg}$ ) were free from clinical evidence of lameness or muscular disease before surgery. The mean duration of anaesthesia in the 12 horses suffering from myopathy was 150 min (90-265). Anaesthesia was uneventful in all horses suffering from myopathy.

The clinical signs varied from mild lameness to severe lameness in which the horse was unable to place weight on the involved limb. The horses with triceps brachii myopathy stood with a characteristic dropped elbow stance of the limb (Rijkenhuizen, Keg and Dik 1994), and were reluctant to bear weight on the affected limb. When the quadriceps was involved, the horses were unwilling to bear weight on the involved limb and knuckled over at the fetlock. The clinical appearance was that of a femoral paralysis. The horse with a longissimus dorsi problem was reluctant to move and had bilaterally very swollen and hard muscles. The recovery of the myopathy took between some hours and 4 days.

Of 77 cattle (duration of anaesthesia: average $114 \mathrm{~min}) 1$ bull (bodyweight $700 \mathrm{~kg}$; duration of anaesthesia $360 \mathrm{~min}$ ) developed a myopathy of the underlying triceps muscle for a few hours.

Tab. 1: Clinical details of the patients with post-anaesthetic myopathy.

Klinische Befunde der Patienten mit Myopathie nach der Narkose.

\begin{tabular}{|c|c|c|c|c|c|c|c|c|}
\hline Breed & Age(yrs) & Weight(kg) & Surg. proc. & Dur. An(min) & Recumbency & Myopathy & Limb & $\begin{array}{l}\text { Dur. of clinical } \\
\text { symptoms (hrs) }\end{array}$ \\
\hline $\mathrm{KWPN}^{*}$ & 10 & 550 & dental surg. & 120 & lat. & front limb & down & 24 \\
\hline KWPN & 4 & 599 & dental surg. & .170 & lat. & front limb & down & 12 \\
\hline KWPN & 6 & 500 & CT-scan & 150 & lat. & hind limb & down & 48 \\
\hline KWPN & 7 & 600 & wound healing & 160 & lat. & front limb & down & 96 \\
\hline KWPN & 14 & 600 & vascular surg. & 265 & lat. & hind limb & up & 72 \\
\hline KWPN & 8 & - & colic surg. & 115 & dor. & front limb & down & 48 \\
\hline KWPN & 5 & - & colic surg. & 180 & dor. & front limb & down & 48 \\
\hline KWPN & 7 & 400 & uterus rupture & 120 & lat. & hind limb & down & 24 \\
\hline Shire & 15 & 840 & colic surg. & 200 & dor. & front $\operatorname{limb}$ & down & 48 \\
\hline Norw. fj. & 8 & 429 & sinusitis & 110 & lat. & front limb & up & 12 \\
\hline KWPN & 4 & 525 & dental surg. & 120 & lat. & front limb & down & 48 \\
\hline Hackney & 6 & - & colic surg. & 90 & dor. & M. long dorsi & down & 12 \\
\hline KWPN & 10 & 602 & cornea rupture & 75 & lat. & radial-nerve paralysis & up & 4 weeks \\
\hline Friesian horse & 2 & 480 & arthroscopy & 75 & dor. & myelomalacie & & euthanasia \\
\hline
\end{tabular}

* KWPN: Dutch warm-blood 


\section{Discussion}

This type of mattress was selected to be tested for use in horses, because human literature, based on the evaluation of CT-scans of subjects supported by various types of beddings, indicates that the use of Waffler polyvinyl air mattresses (EHOB, Indianapolis, U.S.A) results in a significant reduction of compression (Conner and Clack 1993) and may result in a lower incidence rate of ulcers. Animal muscles or deep tissues are more sensitive to pressure than skin and more prone to undergo necrosis (Nola and Vistnes 1980, Daniel, Wheatly and Priest 1985). Therefore the use of these mattresses seemed indicated for animals. Furthermore, the Waffler mattress is used with a very low intraluminal static air pressure. Static air is the only medium that can deliver non-gradient perpendicular pressure on the body and a low pressure is essential in preventing muscle cell damage (Kosiak 1961).

The incidence of $0.9 \%$ of post-anaesthetic myopathy can be considered to be low when compared to the values mentioned in the literature $(0.75$ to $6.4 \%)$. If only the underlying limb and the back problems are considered, the figure even decreases to $0.7 \%$.

It may be concluded that the practical use of the mattresses was good and the life time of the mattresses was sufficient to justify the costs. The system offers pressure control and is easily cleaned. The easy moisture drainage from the patient through the holes is judged to be an additional advantage. To scientifically prove the effect of the use of the Waffler mattresses in reducing the incidence of myopathy a control study should be conducted with muscle pressure measurements. The constant low pressure mattresses are intended to provide an interface surface pressure over the whole undersurface of the body below the average capillary closing pressure of $32 \mathrm{~mm} \mathrm{Hg}$ (Conner and Clark 1993). Whether the interface pressure we measured is really a true reflection of the tissue pressure has still to be determined.

\section{Literature}

Conner L.M. and Clark J.W (1993): In vivo (CT scan) comparison of vertical shearin human tissue caused by various support surfaces. Decubitus, 6, 20-28.

Daniel R.K., Wheatly D.C. and Priest D.L. (1985): Pressure sores and paraplegia: an experimental model. Annals of plastic Surgery, 15 (1), 41-49.

Dodman N.H., Gray L., Williams R. and Goldspink G. (1985): Intracompartmental muscle pressure, temperature and $\mathrm{pH}$ in the horse under general anesthesia. J. of Equine vetrinary Science, 5, 1, $11-15$.

Flaherty D., Nolan A. and Reid J. (1996): Complications during recovery from anaesthesia in the equine patient. Equine vet. Educ 8, 1, $17-22$.

Grandy J.L., Steffey E.P. Hodgson D.S. and Woliner B.S. (1987): Arterial hypotension and the development of post-anesthetic myopathy in halothane-anesthetized horses. Am.J.Vet.Res., 48, 2, 192-197.

Hennig G.E. and Court M.H. (1991): Equine post-anesthetic myopathy: an update. Cont. Ed., 13, 1709-1715.
Klein L. (1978): A review of 50 cases of post-operative myopathy in the horse - intrinsic and management factors affecting risk. Proc. Am. Ass. equine Pract. Conv. 24, 89-94.

Klein L. (1990): Anesthetic complications in the horse. Vet.Clin.N.Am.: Equine Pract. 6, $665-692$.

Kosiak M. (1961): Etiology of decubitus ulcers. Arch. of Phys. Med. Rehabil. $19-24$.

Lindsay W., McDonnell W. and Bignell W. (1980): Equine postanaesthetic forelimb lameness: Intracompartemental muscle pressure changes and biochemical patterns. Am. J. vet. Res. 41, 1919-1924.

Lindsay W., Pascoe P., McDonnell W.N. and Burgess T. (1985): Effects of protective padding on forelimb intracompartmental muscle pressure in the anesthetized horses. Am.J.Vet.Res., 45, 688-691.

Lindsay W.A., Robinson G.M., Brunson D.B. and Majors L.J. (1989): Induction of equine post-anesthetic myositis after halothane-induced hypotension. Am. J. Vet. Res. 50, 3, 404-410.

McCarville E. and Blais D. (1986): Myopathy after general anesthesia in the horse: literature review and a retrospective study of thirteen clinical cases. Med. Vet. Quebec, 16, 17-20.

Nola G.T. and Vistnes L.M. (1980): Differential response of skin and muscle in the experimental production of pressure sores. Scand. J. of Plastic and Reconstructive Surg., 5, 62-66.

Peek M.L. (1993): A case of post-anesthetic myopathy. Equin vet. Educ. 5, 4, 183-186.

Richey M.T., Holland M.S., McGrath C.J., Dodman N.H., Marshall D.B., Court M.H., Norman W.M. and Seeler D.C. (1990): Equine Post-anesthetic Lameness. A retrospective study. Vet. Surg., 19, 5, 392-397.

Rijkenhuizen A.B.M., Keg P.R. and Dik K.J. (1994): True or false radial-nerve paralysis in the horse. Vet.Annual 34, Blackwell Scientific Publications, Oxford. Ed. Raw, Parkinson, 126-133.

Serteyn D., Lavergne L., Coppens P., Mottart E., Philippart C., Micheels M. and Lamy M. (1988): Equine post-anaesthetic myositis: Muscular post ischaemic hyperaemia measured by laser doppler flowmetry. Veterinary record, 30, 126-128.

Serteyn D., Mottart E., Deby C., Deby-Dupont G., Pincemail J., Philipart C. and Lamy M. (1990): Equine postanesthetic myositis: a possible role for free radical generation and membrane lipoperoxidation. Research in Vet. Science, 48, 42-46.

Young S.S. (1993): Post-anaesthetic myopathy Equine vet. Educ. 5 , 4, 200-203.

Weaver B.M.Q., Lunn C.E.M. and Staddon G.E. (1984): Muscle perfusion in the horse. EVJ, 16, 1, 66-68.

White N, and Suarez M. (1986): Change in triceps muscle intracompartmental pressure with reposition and padding of the lowermost thoracic limb of the horse. Am.J.Vet.Res., 47, 2257-2260.

Astrid B.M. Rijkenhuizen

Department of General and Large animal Surgery

Utrecht University,

Yalelaan 12

3584 CM Utrecht

The Netherlands

Tel. (0031) 302531350

Fax (0031) 302537970

email a.rijkenhuizen@hk.dgk.ruu.nl 